\title{
DIMANTRA: LINGUAL-TACTUAL SENSORY MEDIA FOR BALI BLIND TOURISM
}

\author{
Dewa Ayu Dyah Pertiwi Putri, I Gusti Ngurah Adi Rajistha, \\ Dewa Ayu Kadek Claria \\ Universitas Warmadewa, Denpasar, Indonesia \\ E-mail: dyahpertiwiputridewaayu@gmail.com
}

Received: 30 October 2020

Accepted: 15 December 2020

\begin{abstract}
This research aims to design an effective media-Dimantra-to support blind tourism in Bali. The media is intended to help blind tourists to visualize objects and atmosphere in a tourist attraction through lingual narration in the form of audio, equipped with tactual three-dimensional miniatures of the tourist attraction. The theory used in this research was the types of narrative, especially suggestive narrative by Keraf. The method used in collecting data to create the narration audio was observation method supported by note taking technique. Meanwhile, the method used in collecting data related to the effectiveness of Dimantra was interview method supported by closed questionnaire. The results showed that the effective narrative formulation in building visual sensations for blind people was general-specific narrative supported by informative, communicative, and detailed sentences in terms of positions, distances (measurements), directions, textures, and colors. Meanwhile, the effective materials to create proper three-dimensional miniature were newspapers covered with real or semi-real materials such as soft sands to convey beach, hard sands to form rocks, and wet cottons to convey water. Further, Dimantra was considered to be effective in helping blind people to visualize tourist attraction based on the percentage of samples' responses, namely $53 \%$ strongly agree that Dimantra was effective, $37 \%$ agree, $5 \%$ neutral, and $0 \%$ disagree or strongly disagree.
\end{abstract}

Keywords: narrative, three-dimensional miniatures, blind tourists, effective media.

\section{Introduction}

Tourism is one of the largest sectors in Bali Province, which is very prominent internationally. In normal conditions, Bali tourism could reach the quantity of foreign tourist arrivals of 616,706 visits, especially in August 2019 (Badan Pusat Statistik Provinsi Bali, 2019). As a foreign tourist attraction, the tourism sector in Bali should pay more attention to the completeness of public and social facilities in order to maintain the stabilization of tourist visits and improve the quality of hospitality. Facilities are vital in building pleasant tourism. Spillane stated that a tourist destination should fulfill five important elements that could provide satisfaction to tourists. The important elements include: a) Attractions, b) Facilities, c) Infrastructure, d) Transportation, and e) Hospitality (Spillane in Sunarti, 2019). The element of attraction is the most prominent element for most of Bali's tourist attractions. The element that puts forward visual appeal is an essential element, considering that most of Bali's tourist 
attractions are natural tourist destinations that show natural panoramas of Bali's geography. However, not all people are able to enjoy the visual appeal offered by the tourist attractions. One of the parties is blind.

On the other side, the government is increasing the effort to uphold equal opportunity in traveling (Handoyo et al., 2017). In improving the tourism facilities and supporting the goverment effort, this research aimed at initiating the concept of tourist attraction that is friendly to blind tourists with the help of a media called Dimantra-Media Ramah Wisatawan Tunanetra-(Friendly Media for Blind Tourists).

Dimantra is a media designed by the researchers to help blind people in visualizing the main objects in a tourist attraction. Dimantra works by providing detailed descriptions and narrations related to the visuals and atmosphere of a tourist attraction. The narratives were presented in audio form and could be heard through headphones. The narratives were also supported by proper background sounds (natural sounds found in the tourist attraction). Therefore, by listening to the narratives blind people could experience similar trips that the other tourists experience. Besides narration audio, Dimantra was also equipped with threedimensional miniatures of the main objects in the tourist attraction. Therefore, by touching the miniatures, blind people could understand the shape of the objects well. Dimantra could be placed flexibly and strategically in a tourist attraction.

These days, the visual senses of blind people are replaced by the sense of touch and the sense of hearing (Muhammad, Zaien, \& Diwasasri, 2015). For instance, in terms of reading, blind people are generally assisted by Braille books that utilize the sense of touch, audio books that utilize the sense of hearing, or other cutting-edge devices such as BREAD, Finger Reader, and Jaws (Fikriyah, 2016; Muhammad et al., 2015 ; Tyas, Safitri, \& Prabandari, 2014). In line with the above statement, a research in the Philippines that examined the desires of blind people to travel showed that sensory desires of blind people tended to focus on things related to the sense of touch, the sense of hearing, and things that could give impression or experience (Cantero, 2018). For this reason, Dimantra that utilizes the senses of hearing and touch is considered effective as a breakthrough to build friendly blind tourism in Bali.

The researchers have not found specific articles that examined what narrative formulations that are effective in building suitable narrations, especially those aimed for blind people. Thus, the gap to be filled in this research was narrative formulations that effective for blind people. It was embodied by three problems of the research, namely 1) What narrative formulations are effective in building visual sensations for blind people? 2) What materials are effective to create proper three-dimensional miniature that convey visual sensations for blind people? And 3) How effective is Dimantra in helping blind people to visualize tourist attraction? Further, Dimantra is expected to bridge the limitations of blind people in experiencing tourist attraction.

\section{Literature Review}

Research on public places that were diffable-friendly, has been conducted by several researchers. However, a research related to media that could help the diffable people to experience sensation of tourist attractions has never been conducted deeply in Indonesia. Sari and Dewi (2015) in their research about blind people in the city of Semarang revealed that blind people rarely do activities in public spaces. It was caused by the inability to move independently. On the other hand, there were also not many supporting facilities for their activities in public spaces. Based on the research, it could be known that many facilities should 
be considered essential for blind people, such as guidelines, guide blocks, signposts and other supporting activities for the blind.

Tuti and Eka (2019) conducted a research related to the provision of accessible facilities for diffable people in terms of mobility in tourist attractions in Yogyakarta, Handoyo, et al (2017) discussed the rights to travel for diffable people, and Tauda, et al. (2017) discusses the absence of difable people in the development process, the lack of better transportation, and the ease of mobility. Based on the researches, it could be seen that there was a need for development of a diffability-friendly public space, in order to fulfill the rights and needs of difable people.

Several places in Indonesia have paid attention to diffable groups. It could be seen from the empowerment of difable people in Sukoharjo Regency. In a research conducted by Setyaningsih, et al. (2016), the acceptance of people with diffability in society accompanied by adequate facilities could increase their self-confidence and their standard of living. Sunarti (2019) has also conducted a similar research in the city of Batu, which focuses on the facilities provided by tourist objects for visitors with diffability.

In developing a tourist attraction that is blind friendly, it is necessary to provide narratives so that the blind people could enjoy the tourist attraction as if they see the object by their own eyes. Several scientific articles related to methods of building good narratives have been reviewed. Most of the articles tended to provide methods that aimed for school students in building good narrative text (Isroyati, 2016; Much, 2017). Narratives could be made by taking a contextual approach (Much, 2017). Another method of developing narratives according to Isroyati (2016) was by a Field Trip. Those methods were done by consistently making in-depth observations of a topic, so that a good narrative could be built. However, although the two methods have been proven good in building narrative text, it is necessary to refine them in building narrative formulations that specifically aimed for blind people. Several things should be considered, such as the way to describe abstract things like colors.

Before Dimantra, some previous research have created some media to help blind people in gaining information, such as the use of Braille Flashcard media for the ability to read braille both for letters, vocabulary, and simple words. Research that has been conducted by Khairani (2016) provided new image on the use of supporting tools such as flashcards to help groups with visual impairments to meet their needs for information. Muhammad, et al (2015) also created an application called "BREAD" which could be used as a book reading aid for the visually impaired by using a portable scanner in the form of hard text voice which is then converted into sound. In line with the "BREAD" application, Karolina et al (2019) in their research entitled Ideal Model between the Blind and Visual Reader found that there are several obstacles faced by visual readers who have the task of helping blind people in watching films by telling scenes visuals of the film that was watched. Tyas, et al. (2014) analyzed the use of braille image design, which was considered very effective in introducing objects visually to the blind group.

Based on the previous researches, it was revealed that the use of hearing and touch senses played essential roles in fulfilling the needs of blind people in gaining information. Therefore, Dimantra was designed to be effective for hearing and touch senses. In optimizing the hearing sense, an effective lingual narration is needed. In creating an effective narrative, the research used the suggestive narrative theory by Keraf (2010). According to Keraf, suggestive narrative is a narrative that aims to give meaning or evens as an experience. This type of narrative always engages the reader's imagination because its main objective is the meaning of events. The presentation of the suggestive narrative is made by sequences to 
stimulate the reader's imagination. The reader can draw a clear meaning after reading or hearing the narrative. Considering the theory, the audio narration was created in the form of suggestive narrative to put forward the sequence of events happened in a tourist attraction. In optimizing the touch sense, effective materials are needed to convey a real sensation of objects seen in a tourist attraction. The effective materials should be detailed in the term of texture. By optimizing effective narrative and proper three-dimensional miniature, Dimantra is expected to be useful for blind people in experiencing tourist attraction.

\section{Research Method}

This research was designed by using a descriptive qualitative approach with field methods. The stages in this research included: 1) data collection and 2) data analysis. The data collection stage was divided into two sessions, namely a) data collection in a tourist attraction to build narratives and b) data collection related to Dimantra's effectiveness for blind people.

In collecting the data of tourist attraction, the researchers chose Tanah Lot Temple as the tourist attraction for this research. Tanah Lot Temple was chosen because of its complex view and distinctive shape that make it easier in creating three-dimensional miniatures and maximizing the detailed content in building narratives. In building narratives, empirical data includes a list of the main objects contained in Tanah Lot Temple, the situation in the Tanah Lot Temple from morning to evening, the activities was occured at the Temple, and the memorable feelings while being in the Temple were needed. The data source from these empirical data is the Tanah Lot Temple itself. The method used to collect the empirical data was the observation method, which was supported by note-taking technique (Sudaryanto, 2015). The data were used to build narratives to tell and give suggestions to listeners - in this case blind people - so that they seem to be there and witness the tourist attraction with their own eyes. Before the narration listened to blind people, the researchers listened to the audio and examined it by using introspection method (Sudaryanto, 2015).

In collecting the data for the effectiveness of Dimantra analyses, the researchers chose Pertuni Office. Pertuni Office is the official secretariat office of the Indonesian Blind Association (Pertuni) in Denpasar. After the 20 blind samples tried to use Dimantra, the data were collected by using interview method supported by closed questionnaire (Sudaryanto, 2015). The closed questionnaire contained 5-point Likert Scale, namely 1) strongly disagree, 2) disagree, 3) neutral, 4) agree, and 5) strongly agree. After the data were collected, the data further were tabulated and grouped. The data were analyzed based on several variables, namely 1) quality of the narratives, 2) quality of the narration audio, 3) quality of the supporting background sounds, 4) quality of the three-dimensional miniatures, 5) effectiveness of Dimantra in general for blind people. The effectiveness of Dimantra were known based on the scale of the above variables.

\section{Results and Discussion}

\subsection{Effective Narrative Formulations in Conveying Visual Impression of an Object to Blind People}

The narratives were built based on the shape and atmosphere of the Tanah Lot Temple from morning to evening, the activities that took place at the Temple, and the memorable feelings while being in the Temple. The researchers analyzed the narrative formulations first before being tested on the blind samples.

The analyses by the researchers aimed to estimate paragraph pattern and types of sentences that were considered effective in conveying the real nuances of the Tanah Lot 
Temple to blind samples. Based on the analyses, the effective paragraph pattern and types of sentences were: 1) paragraph that has a general-specific pattern supported by 2) informative sentences, 3) communicative sentences, and 4) detailed sentences in terms of positions, directions, textures, and colors. Those characteristics were explained below.

\subsubsection{General-Specific Paragraph Pattern}

Based on the analyses of the researchers, the narratives that have a general-specific pattern were considered to be more structured, clear, and less complicated. General-specific pattern is a paragraph pattern that presenting a broad observation about one topic to specific details in support of the topic. The pattern was chosen with the consideration that the consumers of the narratives were blind people who used more imagination in their daily lives than the other people. Thus, the order of information should be made as comfortable as possible and easy to understand.

...Kau tahu! Warna tebing, pasir, dan karang dari Pura Tanah Lot ini seluruhnya berwarna hitam. Hitam itu adalah warna yang sangat pekat, sepekat rasa kopi tanpa gula. Banyak juga yang menggambarkan warna hitam sebagai warna yang kelam, sekelam hati yang tengah berduka. Meskipun berwarna hitam, nuansa suci dari pura ini sangat mendamaikan hati...

'... You know! The colors of the cliffs, sand and corals of this Tanah Lot Temple are all black. Black is a very intense color, as intense as the taste of unsweetened coffee. Many also describe black as a dark color, as dark as a grieving heart. Even though it is black, the sacred nuance of this temple is very peaceful ...'

Based on the narratives above, it could be seen that the delivery of information was moving from general topic which was the black color of the cliffs, sand, and corals, followed by the explanation of how the color was interpreted by human's senses. If the narratives were read in reverse, it would be specific-general narratives, which were harder to understand. Therefore, the researchers considered the general-specific narrative was better pattern in explaning a topic in the form of recorded narration audio.

\subsubsection{Informative Sentence}

Based on the researcher's analyses, the narratives should have been informative. Informative narratives are narratives that contain useful and interesting sentences that cover both general and specific information about certain topic. Therefore, the narratives for Dimantra was arranged to be effective to provide general information (i.e. the location of the temple, the prestige of the temple among tourists, and reasons why Tanah Lot is considered as one of Bali's iconic destinations) and also provide specific information (i.e. the types of available stall or kiosk there, the description of the temple's shape, and the existence of holy snakes' caves). The informative sentences could be seen through the snippets of narratives below.

General information:

Halo pengunjung yang terhormat, selamat datang di Daya Tarik Wisata Pura Tanah Lot. Daya Tarik Wisata ini terletak di Desa Beraban, Kecamatan Kediri, Kabupaten Tabanan. Pura Tanah Lot merupakan salah satu Daya Tarik 
Dimantra: Lingual-Tactual Sensory Media for Bali Blind Tourism, Dewa Ayu Dyah Pertiwi Putri, I Gusti Ngurah Adi Rajistha, Dewa Ayu Kadek Claria

Wisata Bali yang sangat ikonik dan tersohor hingga ke mancanegara Iho! $\mathrm{Hal}$ tersebut dikarenakan oleh posisi pura yang dibangun di atas sebuah karang, dimana karang tersebut terletak di tengah-tengah laut!

Menarik bukan?...

'Hello dear visitors, welcome to the tourist attraction of Tanah Lot Temple. This tourist attraction is located in Beraban Village, Kediri District, Tabanan Regency. Tanah Lot Temple is one of Bali's most iconic tourist attractions and is famous to foreign countries, you know! This is due to the position of the temple which is built on top of coral, in which the coral is located in the middle of the sea!

Interesting right?...'

Specific Information:

...Nah di atas tebing tersebut, ada banyak kios kerajinan dan restoran yang menyajikan makanan serta minuman yang lezat!

Serunya lagi, restoran-restoran tersebut juga menyediakan meja-meja yang dilengkapi payung, agar pengunjung tidak kepanasan.

'... Well, on top of the cliff, there are many craft stalls and restaurants serving delicious food and drinks!

Even, these restaurants also provide tables equipped with umbrellas, so that visitors will not get sunburn.'

Through the snippets of the narratives, it could be seen that blind people have been well provided with common and specific information that many people should be known after visiting Tanah Lot Temple.

\subsubsection{Communicative Sentence}

Besides being informative, narratives for Dimantra should also be communicative. Therefore, the narratives should contain descriptive sentences as well as exclamation sentences and interrogative sentences. Those were essential in order to provide communicative, interactive, and friendly impression. A communicative, interactive, and friendly narration could make the listeners not easily bored. The communicative and interactive sentences could be observed through the snippets of narratives below.

...Kau dengar kicau-kicau burung yang merdu itu? Rupanya suasana pagi di pantai sama tenangnya dengan di pegunungan ya! Kau tahu? Kini kita berada di tengah-tengah Pantai Tanah Lot Iho! Di siang hari seperti ini, suasana di tepi pantai sangatlah terik. Maka dari itu, sebaiknya kita jalanjalan ke atas tebing yuk!

'... Do you hear the melodious chirping of those birds? It seems that the morning atmosphere on the beach is as calm as in the mountains huh! Hey, now we are in the middle of Tanah Lot Beach, you know! In the daytime, the atmosphere by the beach is very hot. Therefore, let's take a walk up to the cliff!' 
Based on the snippets of narratives above, it could be seen that the interrogative and exclamation sentences during narration could be effective to trigger the listeners to think and concentrate on the narration audio, instead of daydreaming or being sleepy. Besides being effective to trigger the listeners' concentration, the communicative and interactive sentences could also make the listeners feel comfortable, relaxed, and welcome.

\subsubsection{Detailed Sentence about Positions, Distances (Measurements), Directions, Textures, and Colors}

Ideal narratives should also provide detailed information. Detailed information that should be considered in conveying narration to blind people were details related to positions, distances (measurements), directions, textures, and colors. Position is a significant point that closely related to directions and distances. When decribing the area of a place, we should determine a position that will be the starting point before explaining the place around. The starting point will be the endpoint after the end of the explanation. The same method was used to explain the directions. While describing positions and directions, distances (measurements) would also be essential information to provide accurate estimate. The application of this method could be observed through the following snippets narratives.

... Kini kita berada di tengah-tengah Pantai Tanah Lot Iho. Jika kita memandang ke arah selatan, akan terlihat pemandangan Pura Tanah Lot di seberang lautan yang dangkal. Jika kita berbalik arah ke utara, kita akan berhadapan dengan tebing panjang yang sangat tinggi lho! Tingginya mencapai belasan meter.

Nah di sepanjang mulut tebing tersebut, ada banyak jajaran restoran yang menyajikan makanan serta minuman yang lezat!

'... Now we are in the middle of Tanah Lot Beach. If we look to the south, we will see the view of the Tanah Lot Temple across the shallow ocean. If we turn to the north, we will face a long cliff, which is also very high, you know! It is up to a dozen meters high. Along the edge of the cliff, there are many restaurants serving delicious food and drinks!'

Through the snippets narratives, it could be seen that the details regarding the position, direction, and measurement were very essential for blind people to visualize the layout of some objects. Besides the positions, directions, and measurements, detailed explanations of texture were also significant. However, the description of texture should not need to be as detailed as the description of position, direction, distance, and color considering that texture could still be touched the blind people.

Among the details, color was the most difficult thing to describe. It was caused by the facts that most of blind people have never seen colors and the colors themselves were not something that could be observed by the senses of touch and hearing. Therefore, a special method was needed to introduce colors to blind people. In this research, colors were described by matching the aura of certain color with certain feeling or sensation. The application of this method could be observed through the following snippets of narratives.

...Hitam adalah warna yang sangat pekat, sepekat rasa kopi tanpa gula. Banyak juga yang menggambarkan warna hitam sebagai warna yang kelam, sekelam hati yang tengah berduka... 
Dimantra: Lingual-Tactual Sensory Media for Bali Blind Tourism, Dewa Ayu Dyah Pertiwi Putri, I Gusti Ngurah Adi Rajistha, Dewa Ayu Kadek Claria

'... Black is a very intense color, as intense as the taste of unsweetened coffee. Many also describe black as a dark color, as dark as a grieving heart ..'

...Matahari terbenam membuat langit sore menjadi berwarna jingga. Langit jingga yang indah dan hangat ini, memancarkan aura ketenangan dan penyembuhan. Ketenangan yang dipancarkan serupa dengan ketenangan yang kita rasa ketika sampai di rumah untuk beristirahat dan berkumpul dengan keluarga setelah bekerja seharian...

'... The setting sun made the evening sky turn orange. This beautiful and warm orange sky exuded an aura of calm and healing. The serenity emitted is similar to the serenity we feel when we get home to rest and reunite with family after a long day's work ...'

Matching the aura of color with feeling or sensation was considered effective to introduce colors to blind people since they have such sharp sense and feeling. Besides, feelings were the first thing that could be approached by colors after vision.

\subsection{Effective Materials to Create Proper Three-dimensional Miniature}

An effective three-dimentional miniature should be detailed in the term of shape and texture. In building the basic shape of the miniature, a flexible and easy modified material that could be set well was needed. The researchers found that news papers can meet the standard. Besides the basic shape material, decoration materials should also be selected well to convey real sensation of the nature scapes, such as soft sand, hard sands, wet cottons, and artificial plants.

In creating the miniature, news papers was used to form the basic shape of the threedimentional miniature. The three-dimentional miniature was set by masking tape. After the basic shape was ready, it was decorated by soft sand, hard sands, wet cotton, and artificial plants. The soft sands were used to convey beach, the hard sands were used to form rocks, and the wet cottons were used to convey seascapes. The decoration materials should be selected as close as possible to the nature scapes to give real sensation for blind people.

\subsection{The Effectiveness of Dimantra for Blind People}

After building narratives based on the formulations, the researchers create narration audio. The narratives were further narrated while being recorded. The final narration audioaudio that has been cleared from noise and combined with background sounds - was inserted into the three-dimensional miniature of Tanah Lot Temple. Dimantra further was tested on blind people who were selected as samples. The effectiveness of Dimantra was assessed through a closed questionnaire on a 5-point Likert Scale, namely 1) strongly disagree, 2) disagree, 3) neutral, 4) agree, and 5) strongly agree. The points of each variable further calculated and presented in percentage. The results of the effectiveness test were presented below.

\subsubsection{The Quality of the Narratives}

The quality of the narratives was assessed based on 1) the effectiveness of the narratives, 2 ) the informativeness of the narratives, and 3) the communicativeness of the narratives. The percentage of the effectiveness of the narratives namely, $58 \%$ of the samples strongly agreed, 
$37 \%$ of the samples agreed, $5 \%$ of the samples said neutral, and $0 \%$ of the samples disagreed and strongly disagreed. Meanwhile, the percentage of the informativeness of the narratives namely, $63 \%$ of the samples strongly agreed, $32 \%$ of the samples agreed, $5 \%$ of the samples said neutral, and $0 \%$ of the samples disagreed and strongly disagreed. Further, in term of the communicativeness the percentage namely $53 \%$ of the samples strongly agreed, $47 \%$ of the samples agreed, and $0 \%$ of the samples said neutral, disagreed, and strongly disagreed. Therefore, based on the statistics it could be stated that Dimantra was qualified in term of the narratives quality.

\subsubsection{The Quality of the Narration Audio}

The quality of the narration audio was assessed based on 1) the clarity of the narrator's pronunciation, 2) the clarity of the narration audio volume, and 3) the immersion of the narration audio among the background sounds. The percentage of the clarity of the narrator's pronunciation namely, $37 \%$ of the samples strongly agreed, $58 \%$ of the samples agreed, $5 \%$ of the samples said neutral, and $0 \%$ of the samples disagreed and strongly disagreed. Meanwhile, the percentage of the clarity of the narration audio volume namely, $37 \%$ of the samples strongly agreed, $47 \%$ of the samples agreed, $11 \%$ of the samples said neutral, $5 \%$ of the samples disagreed, and $0 \%$ of the samples strongly disagreed. Further, in term of the immersion of the narration audio among the background sounds, the percentage namely $5 \%$ of the samples strongly agreed, $16 \%$ of the samples agreed, $37 \%$ of the samples said neutral, $42 \%$ of the samples disagreed, and $0 \%$ of the samples strongly disagreed. Therefore, based on the statistics it could be stated that the quality of Dimantra's narration audio was sufficiently qualified, though it needed some improvements especially in the term of balance between the volume of narration audio and the volume of background sounds.

\subsubsection{The Quality of the Background Sounds}

The quality of the background sounds was assessed based on 1) the ability in giving real sensation to the narratives, 2) the clarity of the background sounds, and 3) the dominance of the background sounds over narration audio. The percentage of the ability in giving real sensation to the narratives namely, $37 \%$ of the samples strongly agreed, $37 \%$ of the samples agreed, $10 \%$ of the samples said neutral, $16 \%$ of the samples disagreed, and $0 \%$ of the samples strongly disagreed. Meanwhile, the percentage of the clarity of the background sounds namely, $26 \%$ of the samples strongly agreed, $63 \%$ of the samples agreed, $11 \%$ of the samples said neutral, and $0 \%$ of the samples disagreed and strongly disagreed. Further, in term of the dominance of the background sounds over narration audio, the percentage namely $5 \%$ of the samples strongly agreed, $21 \%$ of the samples agreed, $53 \%$ of the samples said neutral, $21 \%$ of the samples disagreed, and $0 \%$ of the samples strongly disagreed. Therefore, based on the statistics it could be stated that the quality of Dimantra's background sounds was sufficiently qualified, even though some improvements were still needed in the term of balance between the volume of background sounds and the volume of narration audio.

\subsubsection{The Quality of the Three-dimensional Miniatures}

The quality of the three-dimensional miniatures was assessed based on 1) the effectiveness of the miniatures in visualizing Tanah Lot Temple, 2) the size of the miniatures was suitable as tactual media, and 3) The texture of the miniatures was suitable in conveying Tanah Lot Temple. The percentage of the effectiveness of miniatures in visualizing Tanah Lot Temple namely, $58 \%$ of the samples strongly agreed, $37 \%$ of the samples agreed, $5 \%$ of the 
samples said neutral, and $0 \%$ of the samples disagreed and strongly disagreed. Meanwhile, the percentage of the size of the miniatures was suitable as tactual media namely, $32 \%$ of the samples strongly agreed, $37 \%$ of the samples agreed, $21 \%$ of the samples said neutral, $10 \%$ of the samples disagreed, and $0 \%$ of the samples strongly disagreed. Further, in term of the texture of miniatures was suitable in conveying Tanah Lot Temple, the percentage namely $53 \%$ of the samples strongly agreed, $32 \%$ of the samples agreed, $5 \%$ of the samples said neutral, $10 \%$ of the samples disagreed, and $0 \%$ of the samples strongly disagreed. Therefore, based on the statistics it could be stated that Dimantra's three-dimensional miniatures were qualified as tactual media in visualizing Tanah Lot Temple.

\subsubsection{The Effectiveness of Dimantra in General for Blind People}

The percentage of the effectiveness of Dimantra in general is $58 \%$ of the samples strongly agreed, $37 \%$ of the samples agreed, $5 \%$ of the samples said neutral, and $0 \%$ of the samples disagreed and strongly disagreed. Therefore, based on the statistics it could be stated that Dimantra was effective and qualified as lingual-tactual sensory media for Bali blind tourism.

\section{Conclusion}

The results show that the effective narrative formulations in building visual sensations for blind people is general-specific narrative supported by informative, communicative, and detailed sentences in terms of positions, distances (measurements), directions, textures, and colors. Meanwhile, the effective materials to create proper three-dimensional miniature are news papers covered with real or semi-real materials such as soft sands to convey beach, hard sands to form rocks, and wet cottons to convey water. Further, Dimantra is considered to be effective and qualified in helping blind people to visualize tourist attractions. It is proven by the percentage of the samples' responses, namely $53 \%$ of the samples strongly agree, $37 \%$ of the samples agree, $5 \%$ of the samples said neutral, and $0 \%$ of the samples disagree or strongly disagree that Dimantra is claimed as effective and qualified media in initiating and supporting Bali blind tourism.

\section{ACKNOWLEDGEMENTS}

The researchers would like to express their gratitude to Warmadewa Research Center (WaRC) for providing funding so that this research could be conducted optimally.

\section{References}

Badan Pusat Statistik Provinsi Bali. (2019). Perkembangan Pariwisata Provinsi Bali Agustus 2019. Retrieved April 2, 2020, from https://bali.bps.go.id/pressrelease/ 2019/10/01/717189/perkembangan-pariwisata-provinsi-bali-agustus-2019.html

Cantero, K. N. G. (2018). Theoretical Analysis on the Foundations of Sensory-Based Tourism for the Blind. Journal of American Academic Research, 6(1). https://www.academia.edu/38494833/Theoretical_Analysis_on_the_Foundations_of _Sensory_based_Tourism_for_the_Blind.

Fikriyah, D. (2016). Implementasi Huruf Braille dalam Pembelajaran Al-qur'an pada Siswa Tunanetra di Kelas VI SMPLB/ A YPAB Surabaya. Surabaya: Universitas Islam Negeri Sunan Ampel Surabaya.

Handoyo, F., Sholihah, A. N., Novitariasari, A., Hani, A. F., Firdausa, Q. P., \& Rahayuningsih, H. (2017). Paket Wisata bagi Difabel di Yogyakarta. Jurnal Pariwisata Terapan, 1(2). Retrieved from https://jurnal.ugm.ac.id/jpt/article/view/30154 
Isroyati. (2016). Peningkatan Kemampuan Menulis Paragraf Narasi dengan Penggunaan Metode Field Trip pada Siswa Kelas IX di SMP Dwiguna Depok. DEIKSIS, 8(3).

Karolina, M. dkk. (2019). Model Komunikasi Ideal antara Tuna Netra dan Visual Reader dalam menonton Film. Jurnal Komunikasi, 14(1). https://journal.uii.ac.id/jurnalkomunikasi/article/view/13804.

Keraf, G. (2010). Argumentasi dan Narasi. Jakarta: Gramedia.

Khairani, M. (2016). Media Flashcard Braille terhadap Kemampuan Membaca Permulaan Tunanetra. Jurnal Pendidikan Luar Biasa. https://jurnalmahasiswa.unesa.ac.id/ index.php/jurnal-pendidikan-khusus/article/view/17862.

Much, H. (2017). Meningkatkan Kemampuan Menulis Karangan Narasi Melalui Pendekatan Kontekstual dengan Inspirator Lingkungan Sekolah Siswa Kelas VII SMP Negeri 1 Sani Nggoang, Manggarai Barat Tahun Pelajaran 2016/2017. JIME, 3(1). http://ejournal.mandalanursa.org/index.php/JISIP/article/view/605.

Muhammad, I., Zaien, H. M., \& Diwasasri, M. A. (2015). "BREAD" Aplikasi Alat Bantu Baca Buku untuk Tunanetra Menggunakan Portable Scanner dengan Metode Hard-Text to Voice.

Sari, O., \& Dewi, K. (2015). Pemanfaatan jalur pemandu tunanetra pada pedestrian di Kota Semarang. Jurnal RUANG, 1(1). https://ejournal2.undip.ac.id/index.php/ ruang/article/view/81.

Setyaningsih, R. dkk. (2016). Pengembangan Kemandirian Bagi Kaum Difabel. Jurnal Sosiologi DILEMA.

Sudaryanto. (2015). Metode dan Aneka Teknik Analisis Bahasa. Yogyakarta: Sanata Dharma University Press.

Sunarti, M. H. (2019). Analisis Fasilitas Pariwisata di Museum Angkut Kota Batu Bagi Pengunjung Penyandang Disabilitas. Jurnal Administrasi Bisnis (JAB), 72(2). Retrieved from http://administrasibisnis.studentjournal.ub.ac.id/index.php/jab/article/view/ 2876

Tauda, A. dkk. (2017). Kesesuaian Pemenuhan Kebutuhan Difabel Tunanetra dan Tunadaksa di Kota Surakarta terhadap Kriteria Kota Ramah Difabel. Region, 12(2). https://www.researchgate.net/publication/334540617_Kesesuaian_Pemenuhan_Keb utuhan_Difabel_Tunanetra_dan_Tunadaksa_di_Kota_Surakarta_terhadap_Kriteria_K ota_Ramah_Difabel.

Tuti, E., \& Eka, N. (2019). DIFA City Tour dan Pemenuhan Kebutuhan Difabel. INKLUSI Journal of Disability Studies, 6 (1). http://ejournal.uin-suka.ac.id/pusat/inklusi/article/ view/1507.

Tyas, D. E., Safitri, M. A., \& Prabandari, T. F. (2014). Desain Gambar Braille sebagai Upaya Mengenalkan Objek Binatang secara Visual pada Anak Penderita Tunanetra. https://media.neliti.com/media/publications/170079-ID-desain-gambar-braillesebagai-upaya-meng.pdf. 